\title{
IMWG Stringent Complete Response
}

National Cancer Institute

\section{Source}

National Cancer Institute. IMWG Stringent Complete Response. NCI Thesaurus. Code C159805.

Complete response, plus normal free light chain ratio and absence of clonal cells in bone marrow biopsy by immune-histochemistry (kappa/lambda ratio less than or equal to 4:1 or greater than or equal to 1:2 for kappa and lambda patients, respectively, after counting at least 100 plasma cells). 